\title{
A study on adjustment of higher secondary school students of durg district
}

\author{
Smt.vandana chauhan, \\ Asstt. Professor, Shiva college Bhilai
}

\begin{abstract}
Present study was conducted on 111 higher secondary students of Durg District, to as certain their adjustment. Adjustment scale by A.K.P, Sinha and R.P. Singh was used for the purpose of data collection. The t-test results indicate that there is significant difference in adjustment of higher secondary school's students and Female students have good adjustment level when compared to the male students.
\end{abstract}

\section{Introduction}

The word adjustment means that behaviour that permits people to meet the demands of the environment. It is also defined as a response to stress and adjust. Different psychologists and the leaders of educational thoughts defined the process of adjustment in different terms.

The concept of adjustment was first given by Darwin, who used it as adaptation' to survive in the physical world.

Adjustment and adaptation are frequently used in the same sense. Initially 'adaptation' was used by person at meant to attempt to survive in physical conditions of environment .later on psychology come out with the new term Adjustment with a broader concept. New Adjustment means behavioral reaction to personal demands and social adjustment is commonly used in our everyday life. It is equally popular in the discipline of psychology, sociology and education. Life is a continuous series of change and challenges. Everyone is facing such situations for his survival or growth. Different persons use different ways to satisfy these needs. The strategy used by the individual to manage this is called adjustment. Sometimes, the efforts of the individual are successful and satisfying, then it is a case of good adjustment. But if a person meet frustration in his efforts continuously, the personality adjustment may not be proper, then it might be a case of maladjustment. Agarwal(2003): The investigator conducted a comparative study of adolescents level of adjustment in relation to the academic success and failue. It was found that successful adolescents were significantly superior in their social emotions and educational adjustment in comparison to unsuccessful addescents. Singh (2006) The study examined the effects of socio, emotional and socio emotional climate of the school and sex on the adjustment of students along with their interactionls effects. Boys were significantly better than girls in their health adjustment at different levels of socio-emotional climate of the school.Parmar Gira B.(2012): The study has been conducted to know the adjustment of secondary school students of Gandhi nagar district. In the study effect of gender and category on the adjustment of secondary school students.

\section{Objectives-}

$>$ To study the total adjustment of higher secondary students.

$>$ To study the education adjustment of higher secondary students.

$>$ To study the emotional adjustment of higher secondary students.

$>$ To study the social adjustment of higher secondary students

$>$ To classify the students based on their adjustment scores.

\section{Hypotheses:-}

- There will be no significant difference in; total adjustment between male and female of higher secondary students.

- There will be no significant difference in education adjustment between ale and female of higher secondary students.

- There will be no significant difference in emotional adjustment between male and female of higher secondary students.

- There will be no significant difference in social adjustment between male and female of higher secondary student 


\section{Methodology-}

Normative survey method of research was used.

\section{Sample-}

For the present study 51 boys and 60 girls were randomly selected from higher secondary schools of Durg district of chhattisgarh state.

Tool used-

"Adjustment Inventory for school students" was constructed by A.K.P.sinha and R.P. Singh with 60 items equally distributed on Emotional ,Social, Educational adjustments was used for total adjustment 5 cores.

\section{Analysis of data and results-}

The analysis of data its interpretation are presented below:

Critical ratio was used to test hypotheses. The results are shown in the following table :-

Table 1

Table showing ' $\mathrm{t}$ ' value of total adjustment of higher secondary male and female students

\begin{tabular}{|l|l|l|l|l|l|l|l|}
\hline gender & $\mathrm{N}$ & MEAN & S.D. & $\mathrm{SE}_{\mathrm{D}}$ & $\mathrm{df}$ & t-value & significant \\
\cline { 1 - 6 } male & 51 & 19.196 & 6.71 & 1.16 & 109 & 4.69 & Signf. \\
\cline { 1 - 5 } Female & 60 & 13.75 & 5.277 & & & & \\
\hline
\end{tabular}

The table-1 Shows that the obtained ' $t$ ' value of 4.69 is greater than the table value of 2.61 at 0.01 significant level for degree of freedom 109. Hence the null hypotheses is rejected. It is thus inferred that there is significant difference in total adjustment between male and female of higher secondary students.

Table-2

Table showing ' $t$ ' value of Emotional adjustment of higher secondary male and female students

\begin{tabular}{|l|l|l|l|l|l|l|l|}
\hline gender & $\mathrm{N}$ & mean & S.D. & $\mathrm{SE}_{\mathrm{D}}$ & $\mathrm{df}$ & t-value & significant \\
\cline { 1 - 7 } male & 51 & 5.254 & 2.82 & .479 & 109 & 4.107 & Signif. \\
\cline { 1 - 4 } female & 60 & 3.283 & 2.05 & & & & \\
\hline
\end{tabular}

The table-2 Shows that the obtained ' $t$ ' value of 4.107 is greater than the table value of 2.61 at 0.01 significant level for degree of freedom 109.Hence the null hypotheses is rejected. It is thus inferred that there is significant difference in emotional adjustment between male and female of higher secondary students.

Table-3

Table showing ' $\mathrm{t}$ ' value of social adjustment of higher secondary male and female students -

\begin{tabular}{|l|l|l|l|l|l|l|l|}
\hline gender & $\mathrm{N}$ & mean & S.D. & $\mathrm{SE}_{\mathrm{D}}$ & $\mathrm{df}$ & $\mathrm{t}$-value & significant \\
\cline { 1 - 6 } male & 51 & 6.94 & 2.78 & 0.2215 & 109 & 1.17 & Non signif. \\
\cline { 1 - 4 } female & 60 & 6.68 & 2.03 & & & & \\
\hline
\end{tabular}

The table- 3 shows that the obtained ' $t$ ' value of 1.17 is less than the table value of 2.61 at 0.01 significant level for degree of freedom 109. Hence the null hypotheses is accepted. It is thus inferred that there is no significant difference in social adjustment of between male and female of higher secondary students.

Table-4

Table showing ' $t$ ' value of educational adjustment of higher secondary male and female students.

\begin{tabular}{|l|l|l|l|l|l|l|l|}
\hline gender & $\mathrm{N}$ & mean & S.D. & $\mathrm{SE}_{\mathrm{D}}$ & $\mathrm{df}$ & $\mathrm{t}$-value & significant \\
\hline male & 51 & 7.039 & 2.99 & 0.53 & 109 & 6.065 & signif. \\
\cline { 1 - 3 } female & 60 & 3.80 & 2.55 & & & & \\
\hline
\end{tabular}

Table-4 shows tat the obtained ' $t$ ' value of 6.065 is grater than the table value of 2.61 at 0.01 significant level fordegree of freedom 109. Hence the null hypotheses is refected. It is thus inferred that there is significant difference in educational adjustment between male and female of higher secondary students

\section{Classification ofstudents adjustment interms of categories scores:-}

The students were classified on the basis of their adjustment into 5 groups. Based on scores obtained in the questionnaire as those with: excellent, Good, Average, unsatisfactory, very unsatisfactory.

The following table-5 shows the sample classification on the basis of their adjustment scores. 
Table-5

Classification of student based on adjustment scores:

\begin{tabular}{|l|l|l|l|l|l|}
\hline category & description & \multicolumn{2}{|c|}{ male } & \multicolumn{2}{|c|}{ female } \\
\cline { 3 - 6 } & & N & percent & N & Percent \\
\hline A & Excellent & 0 & $0 \%$ & $\mathbf{3}$ & $\mathbf{5 \%}$ \\
\hline B & Good & 10 & $19.60 \%$ & $\mathbf{3 0}$ & $\mathbf{5 0 \%}$ \\
\hline C & Average & 27 & $52.94 \%$ & $\mathbf{2 3}$ & $\mathbf{3 8 . 3 3 \%}$ \\
\hline D & Unsatisfactory & 10 & $19.60 \%$ & $\mathbf{4}$ & $\mathbf{6 . 6 6 \%}$ \\
\hline E & $\begin{array}{l}\text { Very } \\
\text { unsatisfactory }\end{array}$ & 4 & $7.84 \%$ & - & - \\
\hline
\end{tabular}

From the table- 5 it can be seen that vast majority of female students i.e. $50 \%$ have good

Adjustment and male students i.e. 52.94\% have average while $38.33 \%$ female are average adjustment and $6.66 \%$ are unsatisfactory whereas in male students $19.60 \%$ are in good adjustment and $19.60 \%$ unsatisfactory adjustment level.So that female are having good and excellent adjustment level than the male.

\section{Conclusion-}

On the basis of results that there is significant difference in total adjustment between male and female of higher secondary students. The findings of the present study indicate that there is distinction between male and female student in their adjustment. The female student have good and excellent adjustment. The female student have good and excellent adjustment level when compared to the male students.

\section{Reference-}

[1] Harbans Singh(2006): “Effect of socio- emotional climate of the school on the adjustment of students." Psycho lingua,2006,36,no.2,page.133-143

[2] Kusum Agarwal(2003); "A comparative study of adolescents level of Adjustment in relation to the academic success and failure." Indian Journal of psychometric and education. Vol34 (2) July 2003.page- 172-176 ISSN-03781003.

[3] Parmar Gira B. (2012) " A study of adjustment of the secondary school students international indexed \& referred research, Journal, June 2012,ISSN- 0974,2832,RNI,RAJBIL 2009/29954,Vol/IV ISSUE 41 